\title{
Opioid-Binding Protein/Cell Adhesion Molecule
}

National Cancer Institute

\section{Source}

National Cancer Institute. Opioid-Binding Protein/Cell Adhesion Molecule. NCI Thesaurus. Code C116962.

Opioid-binding protein/cell adhesion molecule (345 aa, $38 \mathrm{kDa}$ ) is encoded by the human OPCML gene. This protein may be involved in opioid signaling. 